\title{
An immune stimulating complex (ISCOM) subunit rabies vaccine protects dogs and mice against street rabies challenge
}

\author{
M. Fekadu* ${ }^{*}$ J.H. Shaddock*, J. Ekström ${ }^{\dagger}$, A. Osterhaus ${ }^{\ddagger}$, D.W. Sanderlin*, \\ B. Sundquist ${ }^{\S}$ and B. Morein ${ }^{\dagger}$
}

Dogs and mice were immunized with either a rabies glycoprotein subunit vaccine incorporated into an immune stimulating complex (ISCOM) or a commercial human diploid cell vaccine ( $H D C V)$ prepared from a Pitman Moore $(P M)$ rabies vaccine strain. Pre-exposure vaccination of mice with two intraperitoneal (i.p.) doses of $360 \mathrm{ng}$ ISCOM or $0.5 \mathrm{ml} \mathrm{HDCV}$ protected $95 \%$ (38/40) and 90\% (36/40) of mice, respectively, against a lethal intracerebral (i.c.) dose with challenge virus strain (CVS). One $360 \mathrm{ng}$ i.p. dose of ISCOM protected $87.5 \%$ (35/40) of mice against i.c. challenge with CVS. Three groups of five dogs were vaccinated intramuscularly (i.m.) with $730 \mathrm{ng}$ of rabies ISCOM prepared from either the PM or the CVS rabies strains, and they resisted lethal street rabies challenge. Postexposure treatment of mice with three or four $120 \mathrm{ng}$ i.m. doses of ISCOM protected $90 \%(27 / 30)$ and $94 \%$ (45/48), respectively, of mice inoculated in the footpad with street rabies virus, but three doses of HDCV conferred no protection. When four doses of HDCV were administered postexposure, $78 \%(32 / 41)$ of the mice died of anaphylactic shock; $21 \%$ (11/52) of mice had already died of rabies 4 days after the third vaccine dose was administered.

Keywords: Rabies; ISCOM ; human diploid cell vaccine ; postexposure ; treatment ; anaphylactic shock

\section{INTRODUCTION}

Rabies is endemic in most of the world, and rabid dogs are responsible for $>90 \%$ of human rabies deaths ${ }^{1,2}$. Various types of human and animal vaccines are used worldwide for the prevention of rabies. These vaccines are prepared from brain tissue of adult or newborn animals $^{3-6}$, avian tissues ${ }^{7-9}$, or cell cultures ${ }^{10-12}$. The virus strains used for vaccine production are usually derived from the Pasteur fixed rabies virus strain, and the virus is usually inactivated by physical or chemical methods ${ }^{3-13}$. In humans, rabies vaccines are used for both pre- and postexposure immunization, whereas in

*Rabies Laboratory, Viral and Rickettsial Zoonoses Branch, Division of Viral and Rickettsial Diseases, Center of Infectious Diseases, Centers for Disease Control, Public Health Service, US Department of Health and Human Services, Atlanta, GA 30333, USA. TThe National Veterinary Institute, Department of Virology, Biomedical Center, Uppsala, Sweden. ‡National Institute of Public Health and Environmental Hygiene, Bilthoven, The Netherlands. §The National Veterinary Institute, Division of Vaccine Research, Uppsala, Sweden. To whom correspondence should be addressed. (Received 23 January 1991; revised 8 October 1991; accepted 8 October 1991)

0264-410X/92/030192-06

(c) 1992 Butterworth-Heinemann Ltd

192

\footnotetext{
Vaccine, Vol. 10, Issue 3, 1992
}

animals only pre-exposure vaccination is practised. Although the immunological basis of protection following vaccination with inactivated or live attenuated rabies virus vaccines is still not fully understood, it has been shown that both humoral and cellular immune responses are induced by rabies virus vaccines ${ }^{14-16}$

Rabies virus particles contain five different proteins. Closely associated with the nucleoprotein $(N)$ are the non-structural (NS) protein and the virion transcriptase (L). The $\mathrm{N}$-protein represents the group-specific antigen of the genus. The matrix $(\mathrm{M})$ protein and the glycoprotein $(G)$ are located in a lipoprotein envelope, through which spikes of $G$ protein project ${ }^{17-19}$. Spike G-proteins are amphiphilic proteins with at least one subunit of the oligomeric protein inserted into the lipid bilayer of the viral envelope anchoring the spike to the membrane ${ }^{20}$. For rabies virus and most other enveloped viruses, the spike G-proteins are the antigens responsible for stimulating virus-neutralizing antibody ${ }^{21-26}$. It has also been shown that the $\mathrm{N}$-protein (through another mechanism) can induce a protective immune response against rabies infection in animals ${ }^{27,28}$.

One of the crucial points in eliciting immunity and protection is the effective presentation of the desired antigens in a vaccine. To date, relatively little attention 
has been paid to the physical form in which antigens should be presented to the immune system. Since it is now possible to isolate spike proteins as single peplomers from virion or through recombinant-DNA techniques, more immunogenic forms of presentation have become available such as protein micelles, virosomes, or the recently described immune stimulating complexes (ISCOMs). In addition, antigenically and physically defined subunit vaccines can now be formulated ${ }^{15,16,29-33}$. Although protein micelles or liposomes containing multiple copies of virus G-protein have been shown to have considerable immunogenicity ${ }^{34,35}$, this immunogenicity largely depends on the addition of suitable adjuvant $^{36}$.

The ISCOM structure was developed to create a well defined submicroscopic particle, one that presents several copies of antigen exposed on a built-in saponin adjuvant

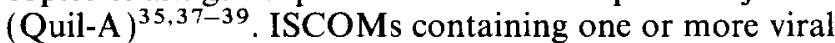
envelope proteins of more than 20 different membrane viruses belonging to eight different virus families have been prepared; all were shown to be highly immunogenic in various animal species, and they induced high protective immunity and good T-cell response ${ }^{37,40-44}$ This report presents data on the serological response and protection from challenge in animals immunized with either an ISCOM containing the rabies G-protein or with a commercial human diploid cell rabies vaccine.

\section{MATERIALS AND METHODS}

\section{ISCOM preparation}

ISCOMS $^{35,45}$ were prepared from either the Pitman Moore (PM) or the challenge virus standard (CVS) rabies strains. Briefly, to $\approx 200 \mathrm{mg}$ purified virus in $8 \mathrm{ml}$ TN-buffer $(0.05 \mathrm{M}$ Tris-hydrochloride, $\mathrm{pH} 7.4,0.1 \mathrm{M}$ $\mathrm{NaCl}$ ), $0.9 \mathrm{ml}$ of a stock solution of detergent Mega-10 (decanoyl- $N$-methylglucamide) (Sigma)* was added to a final concentration of $2 \%$ and left for $2 \mathrm{~h}$ at room temperature. The solubilized virus was layered on top of $10 \%$ sucrose in TN buffer containing $0.2 \%$ Mega- 10 $(\mathrm{w} / \mathrm{v})$, which was layered on $30 \%$ sucrose in TN buffer. The solubilized virus was concentrated at 30000 rev $\min ^{-1}$ for $2 \mathrm{~h}$ at $20^{\circ} \mathrm{C}$ in a TST 41.14 rotor. The top fraction consisting of the sample volume plus the $10 \%$ sucrose layer was collected and Quil-A was added to a final concentration of $0.1 \%$. The mixture was extensively dialysed for $72 \mathrm{~h}$ against three changes of TN buffer at room temperature.

For comparative purposes a commercial human diploid cell vaccine (HDCV) (Imovax, lot no. Z-1355) prepared from the PM strain, and a reference rabies vaccine prepared from CVS (kindly supplied by National Veterinary Laboratory, Iowa, USA) served as controls.

\section{Purification of ISCOM by lectin affinity chromatography}

Approximately $40 \mathrm{mg}$ purified rabies virus was solubilized in $175 \mathrm{ml}$ of $1 \%$ Triton $\mathrm{X}-100$ solution and the viral G-protein was purified by affinity chromatography on a lentil lectin-conjugated Sepharose CL-4B column (Pharmacia Fine Chemicals, Uppsala, Sweden). The solubilized virus material was applied to the lectin column and equilibrated with TN-buffer containing 1\%

* Use of trade name or commercial sources is for identification only and does not imply endorsement by the Public Health Services or the US Department of Health and Human Services
Triton X-100, and the unbound material was washed out of the column with 10 volumes of TN-buffer. Mega-10 was then introduced into the column at a concentration of $0.05 \%$ in $\mathrm{TN}$ buffer. Material specifically bound to the lectin column was eluted with $0.2 \mathrm{M}$ methyl glycopyranoside dissolved in TN-buffer, containing $0.5 \%$ Mega-10. After elution peak, fractions were pooled and concentrated by a $30 \mathrm{~K}$ cut-off ultrafiltration device (Filtron) to a final volume of $25 \mathrm{ml}$. To this concentration $4 \mathrm{mg}$ lipid was added from a stock solution containing $10 \mathrm{mg}$ cholesterol and $10 \mathrm{mg}$ phosphatidyl choline dissolved in water with $20 \%$ Mega-10. Quil-A was added to a final concentration of $0.1 \%$, and the mixture was dialysed for 3 days against three changes of TN-buffer,

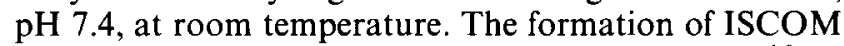
was confirmed by determination of the S-value ${ }^{46}$ in sucrose gradient centrifugation by negative contrast electron microscopy of the gradient fractions.

\section{Animals}

All animals used in this experiment were raised in closed colonies at the Centers for Disease Control animal breeding facility. None of the dogs had been previously vaccinated against rabies, and none had rabies virusneutralizing antibodies (VNA) at the time of inoculation (vaccination).

\section{Determination of antigenic values}

The National Institutes of Health (NIH) potency test $^{47}$ was used to determine and standardize the antigenic values of the ISCOMs, HDCV and reference vaccine ${ }^{48}$. In brief, mice were vaccinated twice intraperitoneally (i.p.) at a one-week interval with fivefold dilutions of each antigen. The vaccinated mice, along with groups of unvaccinated control mice, were then challenged intracerebrally (i.c.) with 30-100 mouse intracerebral lethal dose $50 \%\left(\mathrm{MICLD}_{50}\right)$ of CVS 1 week after the last vaccination. All test antigens were then diluted to obtain similar antigenic values for use in the protection experiments.

\section{Determination of VNA titres}

VNA titres in sera collected from experimental animals were determined by the rapid fluorescent focus inhibition test (REFIT $)^{49}$. Results were expressed in international units (IU) using an international standard reference serum $^{49}$.

\section{Immunofluorescence}

All dog sera were also tested for anti-nucleocapsid antibody titre by the indirect fluorescent antibody (IFA) technique using fluorescein-conjugated rabbit anti-dog globulin.

\section{Pre-exposure vaccination of mice}

Groups of 4-week-old female CDs-ICR mice were vaccinated i.p. on days 0 and 7 with $0.5 \mathrm{ml}$ containing $360 \mathrm{ng} \mathrm{Gp}$ of the respective ISCOM preparations, $0.5 \mathrm{ml}$ (containing 2.5 IU) HDCV, or the reference vaccine prior to i.c. challenge with $10^{3.2}$ MICLD $_{50}$ CVS on day 14 . All mice were observed for 30 days, and the number of dead animals was recorded daily. 


\section{Postexposure vaccination of mice}

To mimic the postexposure treatment of rabies infection, groups of mice were injected in the left hind footpad (FP) with $0.03 \mathrm{ml}$ containing 100-200 FPLD of street rabies (MD 5951) isolated from the salivary gland of a dog in Mexico. The mice were then vaccinated with $0.1 \mathrm{ml}$ HDCV or $0.1 \mathrm{ml}$ ISCOM preparation containing $120 \mathrm{ng}$ once on day $0(24 \mathrm{~h}$ postinjection (PI); three times (days 0,3 and 7); or four times (days $0,3,7$ and $14 \mathrm{PI}$ ). HDCV was given either three times (days 0,3 and 7) or four times (days 0, 3, 7 and 14 PI). The animals were checked daily for clinical signs of rabies.

\section{Pre-exposure vaccination of dogs}

Twenty laboratory-raised beagles, 1 to 3 years of age and of either sex, were divided into four groups of five dogs each. Each dog was vaccinated i.m. in the hind leg. Group 1 was vaccinated with $1 \mathrm{ml}$ containing 5 IU PM whole-virus suspension; groups 2,3 and 4 were vaccinated with corresponding amounts $(730 \mathrm{ng}$ ) of ISCOM antigen prepared from either the PM or the CVS

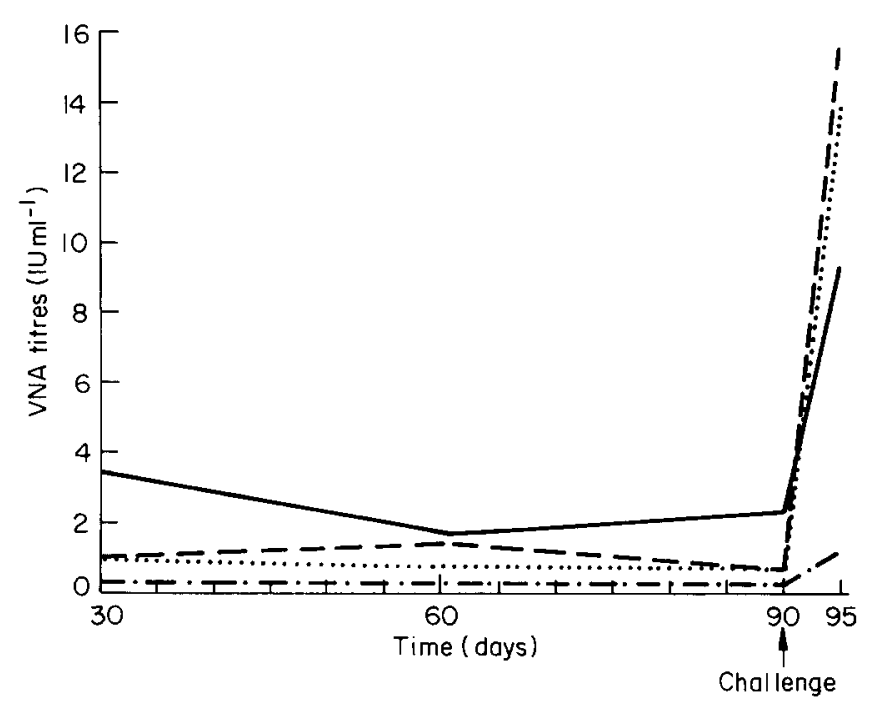

Flgure 1 Geometric mean of rabies VNA titres of dogs vaccinated with whole virus or ISCOM preparations and then challenged with street rabies virus. The VNA induced by the ISCOM preparations was significantly higher $(\rho<0.012)$ than that induced by the whole virus. The prechallenge VNA titres of dogs vaccinated with PM ISCOMs was significantly higher $(p<0.021)$ than those vaccinated with CVS ISCOM preparations. In general the postbooster response of dogs vaccinated with ISCOMs was higher than those vaccinated with whole virus, particularly for CVS groups $(p<0.021)$. The VNA response after challenge of dogs vaccinated with either ISCOM preparation was similar $(p>0.750)$. (-), PM ISCOM; $(---)$, CVS ISCOM; $(\cdots)$, CVS ISCOM (purified); $(-\cdot-\cdot)$, PM whole virus

Table 1 Mortality of mice vaccinated intraperitoneally with either one or two doses of G-ISCOM or two doses of HDCV (7 days apart) and challenged intracerebrally with challenge virus strain (CVS)

\begin{tabular}{llllc}
\hline Group & Vaccine & No. of doses & Inoculated & Deaths (\%) \\
\hline 1 & ISCOM & 1 & 40 & $5(12.5)^{a}$ \\
2 & ISCOM & 2 & 40 & $2(5.0)^{\mathrm{a}}$ \\
3 & HDCV & 1 & 40 & $25(62.5)^{b}$ \\
4 & HDCV & 2 & 40 & $4(10.0)^{a}$ \\
5 & Control & 0 & 40 & $38(95.0)^{b}$ \\
\hline
\end{tabular}

${ }^{a} p<0.05$ compared with groups 3 and 5 .

${ }^{\circ} \rho<0.001$ compared with groups 1,2 and 4
Table 2 Mortality of mice inoculated in the footpad with a street rabies virus and then vaccinated intramuscularly with either ISCOM or HDCV

\begin{tabular}{llllc}
\hline Group & Vaccine & No. of doses & Inoculated & Deaths (\%) \\
\hline 1 & ISCOM & 1 & 30 & $16(53.3)^{b}$ \\
2 & ISCOM & 2 & 30 & $3(10.0)^{c}$ \\
3 & ISCOM & 3 & 48 & $3(6.2)^{c}$ \\
4 & HDCV $^{c}$ & 3 & 30 & $21(70.0)^{b}$ \\
5 & HDCV $^{a}$ & 4 & 41 & $32(78.0)^{b}$ \\
6 & Control & 0 & 30 & $22(73.3)^{b}$ \\
\hline
\end{tabular}

${ }^{a}$ Eleven out of 52 mice died of rabies before the fourth vaccine dose; of the remaining 41 mice, 32 died of anaphylactic shock when the fourth dose was administered.

${ }^{\circ} p<0.001$ compared with groups 2 and 3

${ }^{c} p<0.001$ compared with groups $1,4,5$ and 6

strains. Serum specimens were collected at 30,60 and 90 days for determination of VNA titres against CVS and street rabies virus strains. At the end of the 90-day observation period, all dogs, including five unvaccinated control beagle dogs, were challenged in the masseter muscle with $1 \mathrm{ml}$ of canine salivary gland suspension containing $10^{6.3}\left(\mathrm{MICLD}_{50}\right)$ of a street rabies virus obtained from a dog near the Texas-Mexico border (L-2596). Five days postchallenge, serum specimens were collected to determine the possible booster effect of the challenge virus.

\section{RESULTS}

\section{Pre-exposure vaccination of mice}

Since pre-exposure vaccination of dogs with either PM or CVS ISCOM preparations yielded a high level of immune response (Figure 1), the PM ISCOM was selected for comparison with the HDCV prepared from the same virus strain.

Ninety-five percent (38/40) of mice survived i.c. challenge after vaccination with two i.p. doses of ISCOM containing $360 \mathrm{ng}$ rabies G-protein, and $90 \%$ (36/40) of mice vaccinated with two i.p. doses of $0.5 \mathrm{ml} \mathrm{HDCV}$ also survived. The difference in efficacy between two doses of ISCOM or HDCV was not significant $(p>0.1)$. Of the mice that received only one $360 \mathrm{ng}$ i.p. ISCOM or $0.5 \mathrm{ml}$ HDCV dose, $87.5 \%(35 / 40)$, and $37.5 \%(15 / 40)$, respectively, also survived and the difference between these vaccines is significant $(p<0.05)($ Table 1$)$.

\section{Postexposure vaccination of mice}

Of the 30 mice injected in the footpad with street rabies virus and vaccinated with three $0.1 \mathrm{ml}$ doses of HDCV, most showed signs of rabies 2 days after the third vaccine dose. Twenty-one out of 30 vaccinated mice died of rabies, whereas only three of the 30 mice treated with three doses $(120 \mathrm{ng})$ of ISCOM died. The difference in protection values between three doses of either vaccine is statistically significant $(p<0.001)$ (Table 2 ).

In a second group of 52 mice that received three $0.1 \mathrm{ml}$ i.m. doses of HDCV, $11(21 \%)$ died of rabies 4 days after the third dose was administered. When the fourth HDCV dose was administered on day 14, 32 of the remaining 41 mice $(78 \%)$ died, with no signs or severe reaction, of generalized convulsion (anaphylactic shock ) occurring immediately after their inoculation (Table 2).

Only three out of 48 challenged mice $(6 \%)$ died after receiving four $120 \mathrm{ng}$ i.m. doses of ISCOM, and 16 out 
of 30 mice $(53 \%)$ administered one dose of $120 \mathrm{ng}$ ISCOM. Protection values of three doses of HDCV or one dose of ISCOM were not significantly different from the negative control $(p>0.1)$ (Table 2).

\section{Pre-exposure vaccination of dogs}

All dogs vaccinated with an ISCOM, regardless of the virus strain used for preparation of the ISCOM, and those vaccinated with whole virus were protected against a street rabies virus challenge, whereas all unvaccinated control dogs died of rabies. Pre- and postchallenge rabies VNA titres of dogs are depicted in Figure 1. Although the antigenic value of the ISCOM preparations and the whole virus inoculum were similar, the VNA induced by the ISCOM preparations was significantly higher $(p<0.012)$ (Figure 1). The geometric mean prechallenge VNA titre (GMT) of dogs immunized with PM whole virus vaccine (group 1) was $0.230 \mathrm{IU}$ (range $0.2-0.4 \mathrm{IU}$ ), whereas the postchallenge titre was $1.222 \mathrm{IU}$ (range $0.1-9.3 \mathrm{IU})$. The geometric mean prechallenge VNA titre of dogs vaccinated with the ISCOM prepared from PM virus (group 2) was 2.289 IU (range 0.9-5.7 IU), and the postchallenge titre was 9.359 IU (range 2.0-3.86 IU) (Figure 1). The prechallenge VNA of dogs in group 2 was significantly higher $(p<0.021)$ than in groups 3 and 4 . In general the booster response of dogs vaccinated with ISCOMs was higher than those vaccinated with whole virus, particularly for groups $3(p<0.021)$ and 4 $(p<0.021)$. The booster response of dogs vaccinated with ISCOM preparations was similar $(p>0.750)$.

Five dogs vaccinated with whole virus (group 1) had a low detectable anti-N titre whereas the remaining 15 dogs given ISCOMs were negative (data not shown), indicating that the rabies G-protein preparation used in this experiment was relatively pure and did not induce any detectable amounts of antinucleocapsid antibody.

\section{DISCUSSION}

Limited information exists on experimental subunit rabies vaccines. However, recently rabies virus $\mathrm{G}$-protein vaccinia-recombinant vaccines have been successfully used to immunize animals ${ }^{50}$, and rabies $G$-protein presented in a virosome was also shown to be more immunogenic than that presented as protein micelle or killed vaccine ${ }^{51}$

In the present experiment, ISCOM vaccines prepared from two different rabies virus strains were compared with conventional human rabies vaccine in animal models (dogs and mice). No obvious differences in VNA response or protection were observed between the lectin-purified or the crude detergent-solubilized CVS ISCOM preparations, but the PM ISCOM had higher VNA titre than CVS, especially at 90 days after vaccination. One dose of $0.73 \mu \mathrm{g}$ of either of the ISCOMs induced significantly higher VNA titre than a whole virus vaccine with similar antigen value. Most remarkable was the high anamnestic response in animals vaccinated with the ISCOMs and then challenged with a street rabies virus, signifying that a memory cell response was induced.

The efficacy of rabies vaccination has been shown in animals many times, and appears to correlate with the presence and degree of neutralizing-antibody titre ${ }^{26.52}$. In some experiments, however, it has been documented that animals that fail to elicit neutralizing-antibody titre after exposure to viral antigen may resist rabies virus challenge $^{53}$, whereas others which had neutralizingantibody titre succumbed ${ }^{26,54}$. ISCOM-borne antigens induce cell-mediated immunity (CMI) efficiently ${ }^{41}$ and they are unique (as shown with HIV-1 and influenza viral antigens) in their capacity to induce cytotoxic T-lymphocytes (CTL) which are $\mathrm{CD} 8^{+}$and under the restriction of $\mathrm{MHC}$ class 1 . This class of CTL has been shown to confer protection against many membrane viruses, indicating that $\mathrm{CMI}$ to rabies virus might also be important for protection ${ }^{55,56}$.

Unlike other human viral vaccines, rabies vaccines are mainly used for postexposure treatment of exposed individuals, and the induction of virus-neutralizing antibody has been the parameter measured in judging the protection against rabies ${ }^{52}$. In humans and animals, however, administration of vaccine alone has rarely been demonstrated to prevent disease, unless anti-rabies serum (or globulin) was administered simultaneously ${ }^{6,7,10,51}$, 57-59. Protective postexposure effect is not conferred by anti-rabies serum alone, indicating that vaccine activates protective mechanisms besides the neutralizing-antibody response ${ }^{51,57-61}$. Whether the protection provided by postexposure immunization is to a greater or lesser extent dependent on CMI is not known. However, it is shown that ISCOMs containing the F-protein of measles virus efficiently induce CMI in mice including the $\mathrm{T}_{\mathrm{H}} 1$ type of cells which after adoptive transfer provided protection against i.c. virus challenge. These cells also produced IL-2 and gamma interferon ${ }^{40}$. It was also shown that envelope proteins of influenza virus and HIV-1 incorporated in ISCOMs induce IL-2 gamma interferon producing cells more efficiently in mice than micelles of the same antigen. In the case of influenza virus, ISCOMs were more efficient than the live virus (B. Morein, unpublished data).

In the present study, three $120 \mathrm{ng}$ rabies G-protein ISCOM doses administered postexposure protected $90 \%$ of rabies-infected mice, whereas HDCV gave no protection, even though both antigens were prepared from the same vaccine strain. Two ISCOM doses were equally effective, indicating that rabies ISCOMs are effective in postexposure treatment of mice without the additional application of anti-rabies globulin. The use of commercial vaccine, however, was not only ineffective in postexposure treatment of rabies-infected mice but also caused fatal hypersensitivity reaction similar to the systemic allergic reactions, ranging from hives to anaphylactic shocks, reported in humans in both pre- and postexposure immunization ${ }^{62-65}$. Thus, with ISCOM vaccines it may be possible eventually to eliminate antiserum from postexposure rabies treatment, avoiding the expense and adverse reactions ${ }^{61-65}$

We have demonstrated that very low quantities of rabies G-proteins incorporated into ISCOM (without the additional application of anti-rabies globulin ) protect mice against lethal rabies challenge when administered as a postexposure vaccine. Rabies ISCOM and whole virus vaccines were also successfully used for preexposure vaccination of dogs. Human postexposure immunization with ISCOMs may be possible, especially in areas where anti-rabies globulins may not be available for economic or technical reasons. Postexposure trials in other primates and other laboratory animals may be carried out to determine whether ISCOM subunit vaccines can be recommended for use in humans. 


\section{ACKNOWLEDGEMENTS}

The authors are grateful to Drs G.M. Baer and D.B. Fishbein for their valuable comments and assistance, and Ms S.L. Ford for photographic assistance. (C) US Government.

\section{REFERENCES}

1 WHO World Survey of Rabies XXII, World Health Organization Geneva, 1988

2 Fekadu, M. Canine rabies. In: Natural History of Rabies, 2nd edn (Ed. Baer, G.M.) CRC Press, Boca Raton, 1991, pp. 367-378

3 Seligmann, S. Jr. Semple-type vaccine. In: Laboratory Techniques in Rabies, 3rd edn (Eds Kaplan, M.M. and Koprowski, H.), World Health Organization, Geneva, 1973, pp. 193-198

4 Lepine, P. Fermi-type vaccine. In: Laboratory Techniques in Rabies 3rd edn (Eds Kaplan, M.M. and Koprowski, H.), World Health Organization, Geneva, 1973, pp. 199-200

5 Karakujumcan, M.K., Pariz, B.M. and Solovev, V.D. Suckling Ra vaccine. In: Laboratory Techniques in Rabies, 3rd edn (Eds Kaplan, M.M. and Koprowski, H.), World Health Organization, Geneva, 1973 pp. 213-215

6 Fuenzalida, E. Suckling mouse brain vaccine. In: Laboratory Techniques in Rabies, 3rd edn (Eds Kaplan, M.M. and Koprowski, H.), World Health Organization, Geneva, 1973, pp. 216-220

7 Koprowski, H. and Cox, H.R. Studies on chick embryo adapted rabies virus. I. Culture characteristics and pathogenicity. J. Immunol $1948,60,533-554$

8 Powell, H.M. and Culbertson, C.G. Action of street rabies vaccine derived from embryonated duck eggs against street rabies virus. Proc. Soc. Exp. Biol. Med. 1959, 101, 801-803

9 Hoskins, J.M. Duck-embryo vaccine. In: Laboratory Techniques in Rabies, 3rd edn (Eds Kaplan, M.M. and Koprowski, H.), World Health Organization, Geneva, 1973, pp. 243-255

10 Bahmanyar, M., Fayaz, A., Nour-Salehis, N., Mohammadi, M. and Koprowski, H. Successful protection of humans exposed to rabies infection. Rabies postexposure treatment with new human diploid cell vaccine and antirabies serum. JAMA 1976, 236, 2751-2754

11 Fang-Tao, L., Shu-Beng, C., Guan-Fu, W., Fan-Zhen, Z., Nai-Min, C. and Ji-Zui, F. Study of the protective efficacy of primary hamster kidney cell rabies vaccine. J. Infect. Dis. 1986, 154, 1047-1048

12 Fournier, P., Motagnon, B., Vincent-Falquet, J.C., Ajjan, N., Drucker, J. and Roumiantzeff, M.A. New vaccine produced from rabies cultivated on vero cells. In: Improvements in Postexposure Rabies Treatment (Eds Vodpija, I., Nicholson, K.A., Smerdel, S. and Bijok, U.) Zagreb Institute of Health, Zagreb, 1985, pp. 115-121

13 Habel, K. Ultraviolet-light irradiation for inactivation of vaccine. In Laboratory Techniques in Rabies, 3rd edn (Eds Kaplan, M.M. and Koprowski, H.), World Health Organization, Geneva, 1973, pp. 193-198

14 Wunner, W.H., Dietzschold, B., Cutis, P.J. and Wiktor, T.J. Rabies subunit vaccines. J. Gen. Virol. 1983, 64, 1649-1656

15 Crick, J. and Brown, F. Viral subunit rabies vaccination. Nature 1969 222, 92

16 Thibodeau, L., Boudreault, A. and Perrin, P. Immunosome technology: an approach to efficient and safe influenza and rabies vaccine. In: Biotechnology: Applications and Research (Eds Cheremisinoff, P. and Quellette, R.). Lancaster, PA, 1985, pp. 370-379

17 Tordo, W.H., Pock, O., Ermine, A., Keith, G. and Rougeon, F. Walking along the rabies genome: Is the large $G-L$ intergenic region remnant gene? Proc. Nat/ Acad. Sci. USA 1986, 83, 3914-3918

18 Wunner, W.H., Larson, J.K., Dietzschold, B. and Smith, C.L. The molecular biology of rabies viruses. Rev. Infect. Dis. 1988, 10 $771-784$

19 Clark, H.K. Systems for assay and growth of rhabdoviruses. In: Rhabdoviruses Vol. 1 (Ed. Bishop, D.H.L.), CRC Press, Boca Raton 1979, pp. 23-41

20 Morein, B. and Simons, K. Subunit vaccines against enveloped viruses: Virosomes, micelles and other protein immunocomplex. Vaccine 1985, 3, 83-93

21 Wiktor, T.J., Doherty, P.C. and Koprowski, H. In vitro evidence of cell-mediated immunity after exposure of mice to both live and inactivated rabies virus. Proc. Natl Acad. Sci. USA 1977, 74, 334-338

22 Tsiang, $H$. and Lagrange, P.H. In vitro detection of cell-mediated immunity in street rabies virus infection in mice. J. Gen. Virol. 1980, 47, 183-191

23 Wiktor, T.J. and Koprowski, H. Antigenic variants of rabies virus.
J. Exp. Med. 1980, 152, 843-851

24 Wiktor, T.J., Gyorgy, E., Schlumberger, H.D., Sokol, F. and Koprowski, $H$. Antigenic properties of rabies components. J. Immunol. 1973, 110, 209-276

25 Sikes, R.K., Cleary, W.F., Koprowski, H., Wiktor, T.J. and Kaplan, M.M. Effective protection of monkeys against death from street virus by post exposure administration of tissue culture rabies vaccine. Bull. WHO 1971, 45, 1-11

26 Cox, J.H., Dietzschold, B. and Schneider, L.G. Rabies virus glycoprotein. II. Biological and serological characterization. Infect. Immun. 1977, 16, 754-759

27 Reid-Sanden, F.L., Sumner, J.W., Smith, J.S., Fekadu, M., Shaddok J.H. and Bellini, W.J. Expression of rabies virus nucleoprotein (N) gene by recombinant baculovirus. Proc. Annual Meeting American Society for Microbiology, Jekyll Island, October 1988

28 Morein, B., Sharp, M., Sundquist, B. and Simons, K. Protein subunit vaccines of parainfluenza type 3 virus: Immunogenic effect in lambs and mice. J. Gen. Virol. 1983, 64, 1557-1569

29 Dietzschold, B., Wang, H., Rupprecht, C.E., Celis, E., Tollis, M., ErtI, $\mathrm{H}$. et al. Induction of protective immunity against rabies by immunization with rabies virus ribonucleoproteins. Proc. Natl Acad. Sci. USA 1987, 84, 9165-9169

30 Morgan, A.J., Finerty, S., Lövgren, K., Scullion, F.T. and Morein, B. Prevention of Epstein-Barr (EB) virus induced lymphoma in cottontop tamarins by vaccination with the EB virus envelope glycoprotein gp 340 incorporated into iscom. J. Gen. Virol. 1988, 69, 2093-2096

31 Kieny, M.P., Lathe, R., Drillien, R., Spehner, D., Skory, S., Schmitt D. et al. Expressing rabies glycoprotein from a recombinant vaccinia virus. Nature 1984, 312, 163-166

32 Morein, B., Lövgren, K., Höglund, S. and Sundquist. B. The Iscom An immunostimulating complex. Immunol. Today 1987, 8, 333-338

33 Morein, B., Sundquist, B., Höglund, S., Dalsgaard, K. and Osterhaus, A. Iscom, a novel structure for antigenic presentation of membrane proteins from envelope viruses. Nature (London) 1984, 308, $457-460$

34 Dietzschold, B., Schneider, L.G. and Cox, L.H. Serological characterization of three major proteins of vesicular stomatitis virus. J. Virol. 1974, 14, 1-7

35 Morein, B., Helenius, A., Simons, K., Pettersson, R., Kaariainen, L. and Schirrmacher, V. Effective subunit vaccines against enveloped animal virus. Nature 1978, 276, 715-718

36 Bomford, R. The comparative selectivity of adjuvant for humora and cell-mediated immunity. II. Effect of delayed-type hypersensitivity in the mouse and guinea pig, and cell-mediated immunity to tumor antigens in the mouse for Freund's incomplete and complete adjuvant, Alhydrogel, Corynebacterium parvum, Bordetella pertussis, muramyl dipeptide and saponin. Clin. Exp. Immunol. 1980, 39, 435-441

37 Laver, W.R. and Webster, R.G. Preparation and immunogenicity of an influenza virus haemagglutinin and neuraminidase subunit vaccine. Virology 1976, 69, 511

38 Dalsgaard, K. Saponin adjuvant. III. Isolation of a substance from Quilloja saponaria Molina with adjuvant activity in foot and mouth disease vaccine. Arch. Ges. Visusforsch. 1974, 44, 243-254

39 Dalsgaard, $K$. Assessment of the dose of the immunological adjuvant Quil $A$ in mice and guinea pigs using sheep red blood cells as model antigens. Zentralb/. Vet. Med. 1984, B31, 718-720

40 DeVries, P., Van Binnendjiik, R.S., Van der Marel, P., Van Wezel, A.L., Voorma, H.O., Sundquist, B. et al. Measles virus fusion protein presented in an immune stimulating complex (Iscom) induces hemolysis-inhibiting and fusion-inhibiting antibodies, virus-specific T cells and protection in mice. J. Gen. Virol. 1988, 69, 549-559

41 Höglund, S., Dalsgaard, K., Lövgren, K., Sundquist, B., Osterhaus, $A$. and Morein, B. Iscoms and immunostimulation with viral antigens. In: Subcellular Biochemistry, Vol. 15. (Ed. Harris, J.R.) Plenum, New York, 1989, pp. 39-68

42 Osterhaus, A., Weijer, K., Utydehaag, F., Jarrett, O., Sundquist, B. and Morein, $B$. Induction of protective immune response in cats by vaccination with feline leukemia virus iscom. J. Immunol. 1985, 135, $591-596$

43 Osterhaus, A., Weijer, K., Utydehaag, F., Jarrett, O., Sundquist, B. and Morein, $B$. Induction of protective immune response in cats by vaccination with feline leukemia virus iscom and inactivated FeLV vaccine. Vaccine $1989,7,137$

44 Åkerblom, L., Höglund, S., Strömstedt, K., Osterhaus, A. and Morein, B. Formation and characterization of FeLV iscoms. Vaccine 1989 , 7. $142-145$

45 Lövgren, $K$. and Morein, B. The requirement of lipids for the formation of immunostimulating complexes (iscoms). Biotechnol. Appl. Biochem. 1988, 10, 161-172 
46 Martin, R.G. and Ames, B.N. A method for determining the sedimentation behavior of enzymes: application to protein mixtures J. Biol. Chem. 1961, 236, 1372-1379

47 Seligmann, E.B. Jr. The NIH test for potency. In: Laboratory Techniques in Rabies, 3rd edn (Eds Kaplan, M.M. and Koprowski H.), World Health Organization, Geneva, 1973, pp. 279-286

48 Fekadu, M., Shaddock, J.H., Sanderlin, D.W. and Smith, J.S. Efficacy of rabies vaccines against Duvenhage virus isolated from European house bat (Eptesicus serotinus), classic rabies and rabies-like viruses. Vaccine 1988, 6, 533-539

49 Smith, J.S., Yager, P.A. and Baer, G.M. Rapid tissue culture test for determining rabies-neutralizing antibody. In: Laboratory Techniques in Rabies, 3rd edn (Eds Kaplan, M.M. and Koprowski, H.), World Health Organization, Geneva, 1973, pp. 354-357

50 Wiktor, T.J., MacFarlan, R.I., Reagan, K.J., Dietzschold, B., Curtis, P.J., Wunner, W.H. et al. Protection from rabies by a vaccinia virus recombinant containing the rabies glycoprotein gene. Proc. Nat Acad. Sci. USA 1984, 81, 7194-7198

51 Perrin, P., Thibodeau, L. and Sureau, P. Rabies immunosomes (subunit vaccine) structures and immunogenicity. Pre- and postexposure studies. Vaccine 1985, 3, 325-332

52 Bunn, T.O., Ridpath, H.D. and Beard, P.D. The relationship between rabies antibody titer in dogs and cats and protection from challenge. Rabies Int. Exch. 1984, 11, 9-12

53 Fekadu, M. and Shaddock, J.H. Peripheral distribution of virus in dogs inoculated with two strains of rabies virus. Am. J. Vet. Res. 1984, 45, 724-729

54 Prabhakar, B.S. and Nathanson, N. Acute rabies death mediated by antibody. Nature (London) 1981, 290-1, 590

55 Takahashi, H., Takeshita, T., Morein, B., Putney, S., Germain, R.N. and Berzofsky, J.A. Induction of $\mathrm{CD}^{+}$cytotoxic cells by immunization with purified HIV-1 envelope protein in ISCOMs. Nature 1990, 344, 873-875
56 Jones, P.D., Tha Hla, R., Morein, B. and Ada, G.L. Cellular immune response in the murine lung to local immunization with influenza A virus glycoproteins in micelles and iscoms. Scand. J. Immunol. $1988,27,645-652$

57 Baer, G.M. and Cleary, W.F. A model in mice for the pathogenesis and treatment of rabies. J. Infect. Dis. 1972, 136, 520-527

58 Wiktor, T.J. Historical aspects of rabies treatment. In: World Debt to Pasteur (Eds Koprowski, H. and Plotkin, S.), Alan R. Liss, New York, 1985, pp. 141-151

59 Baltazard, M. and Ghodossi, M. Prevention of human rabies. Treatment of persons bitten by rabid wolves in Iran. Bull. WHO 1954, 10, 797-803

60 Baer, G.M. and Yager, P.A. A mouse model for post-exposure rabies prophylaxis: The comparative efficacy of two vaccines and antiserum administration. J. Gen. Virol. 1977, 36, 51-58

61 Fang-Tao, L., Shu-Beng, C., Yin-Zhon, W., Chen-Zhe, S., Fan-Zhen, $Z$. and Guan-Fu, W. Use of serum and vaccine in combination for prophylaxis following exposure to rabies. Rev. Infect. Dis. 1988, 10 $766-770$

62 Centers for Disease Control. Systemic allergic reaction following immunization with human diploid cell rabies vaccine. Morbid. Mortal. Week. Rep. 1984, 33, 185-187

63 Bernard, K.W. Smith, P.W Kader, F.J. and Moran, M.J. Neuroparalytic illness and human diploid cell rabies vaccine. JAMA 1982, 248, 3136-3138

64 Dressen, D.W. Fishbein, D.B., Brown, J., Bernard, K.W, Kemp, D.T. Brown, D.W.J. et al. Immune complex-like disease in two groups of persons following a booster dose of rabies human diploid cell vaccine. Vaccine 1985, 2, 357-364

65 Anderson, M.C., Baer, H., Frazier, D.J. and Quinnan, G.V. The role of specific $\mathrm{lgE}$ and beta-propiolactone in reactions resulting from booster doses of human diploid cell rabies vaccine. J. Allergy Clin. Immunol. 1987, 80, 861-868 